\title{
Öğretmenlerin Örgütsel Sessizlik Algılarının Kıdem Değişkeni Açısından İncelenmesi: Bir Meta-Analiz Çalışması
}

\author{
Orhan YILMAZ \\ Kırşehir Ahi Evran Üniversitesi, \\ Sosyal Bilimler Enstitüsü, Yüksek Lisans Öğrencisi, Kırşehir, orhanyilmaz38@ hotmail.com \\ ORCID ID: https://orcid.org/0000-0003-2254-1361 \\ Tufan AYTAÇ \\ Kırşehir Ahi Evran Üniversitesi, \\ Eğitim Fakültesi, Eğitim Bilimleri Bölümü, Eğitim Yönetimi Anabilim Dalı, Kırşehir, tufana60@gmail.com \\ ORCID ID: https://orcid.org/0000-0002-6103-3530
}

Araştırma Makalesi

Geliş Tarihi: 06.08.2019

Revize Tarihi: 26.11 .2019

DOI: $10.31592 /$ aeusbed.602542

Atıf bilgisi

Yılmaz, O. ve Aytaç, T. (2019). Öğretmenlerin örgütsel sessizlik algılarının kıdem değişkeni açısından incelenmesi: Bir meta-analiz çalışması. Ahi Evran Üniversitesi Sosyal Bilimler Enstitüsü Dergisi, 5(2), 408-425.

ÖZ

$\mathrm{Bu}$ çalışmanın temel amacı, öğretmenlerin örgütsel sessizlik algılarında kıdemlerinin etkisini ortaya koymaktır. Çalışmanın kapsamına Türkiye'de ki okullarda öğretmenlerin örgütsel sessizlik algılarını konu alan yüksek lisans ve doktora tezi ile araştırma makalelerinden dâhil edilme kriterlerine uygun 33 çalışma alınmıştır. Bu çalışmada, araştırma sonuçlarını sentezlemede meta-analiz yöntemi kullanılmıştır. Araştırma sonucunda 10 yıl ve üstü kıdeme sahip öğretmenler lehine rastgele etkiler modeline $(\mathrm{d}=-0,08)$ göre istatistiksel olarak önemsiz düzeyde bir etki büyüklüğü belirlenmiştir. Yapılan moderatör analizi sonucunda yayın türüne $(p=0,74)$, okul türüne $(p=0,41)$, öğretim kademesine $(p=0,53)$, araştırmanın yapıldığı bölgeye $(p=0,33)$, ögretmenin unvanına $(p=0,33)$ ve araştırmacının cinsiyetine $(p=0,59)$ göre çalışmaların etki büyüklüklerinin farklılaşmadığı belirlenmiştir. Öğretim kademesi açısından okulöncesi eğitim $(\mathrm{d}=-0,32)$ ve özel eğitim $(\mathrm{d}=0,10)$ kademesinde çalışan 10 yıl ve üstü kıdeme sahip öğretmenlerin örgütsel sessizlik algıları diğer kademede çalışan öğretmenlere göre daha yüksek düzeyde çıkmıştır. Araştırmaların yapıldığı bölgeler bağlamında Güneydoğu Anadolu bölgesi $(\mathrm{d}=0,10)$ dışında yapılan araştırmaların sonuçları, 10 yıl ve üstü kıdeme sahip öğretmenlerin örgütsel sessizlik algılarının yüksek olduğunu göstermektedir. Ayrıca araştırmalara ait etki büyüklükleri açısından 10 yıl ve üstü kıdeme sahip öğretmenler lehine örgütsel sessizlik algılarının yüksekliğinin devam ettiği görülmektedir.

Anahtar Kelimeler: Örgütsel sessizlik, öğretmen, kıdem, meta-analiz.

\section{An Analysis of Teachers' Perceptions of Organizational Silence in terms of Seniortiy Variable: A Meta-Analysis Study}

\begin{abstract}
The main purpose of this study is to determine the effect of seniority in teachers' perception of organizational silence. Thirty-three studies deemed meeting the inclusion criteria were chosen from MA and PhD thesis and dissertations with articles about teachers' perceptions of organizational silence in schools in Turkey to be used in this study. In this study, one of the methods of synthesizing the research results, meta-analysis method was used. As a result of the study, a statistically sinsignificant effect size was determined according to the random effects model $(\mathrm{d}=-0.08)$ in favor of teachers who had seniority of 10 years or more. As a result of the moderator analysis, the type of publication $(p=0.74)$, school type $(p=0.41)$, teaching level $(p=0.53)$, the region of the research $(p=0.33)$, the title of the teacher $(p=0,33)$ and gender of the researcher $(p=0.59)$. In terms of the teaching level, pre-school education $(\mathrm{d}=-0.32)$ and special education $(\mathrm{d}=0.10)$ level of teachers with 10 years and more seniority perceptions were higher than the teachers working in the other level. The results of the surveys conducted outside the Southeastern Anatolia region $(d=0.10)$ in the context of the provinces where the researches were conducted show that teachers with a seniority of 10 years and more have higher perceptions of organizational silence. In addition, in terms of the effect sizes of the researches, it is seen that there is a tendency in terms of seniority difference in favor of teachers who have seniority of 10 years or more.
\end{abstract}

Keywords: Organizational silence, teacher, seniority, meta-analysis. 


\section{Giriş}

Eğitim örgütlerinde özellikle okullarda yöneticilerin ve öğretmenlerin yaşadığı stres, kayg1, olumsuz çalışma koşulları, iş güvencesinin olmaması, tükenmişlik ve iş doyumunun düşüklüğü gibi faktörler gerek okulun gerekse çalışanların etkiliğini düşürmektedir. Bu olumsuz koşullar devam ettiğinde ya da çalışanların bunları ortadan kaldırmaya yönelik çabaları sonuçsuz kaldığında, örgütsel sessizlik kendini hissettirmektedir.

Küreselleşme sürecinde eğitim örgütlerin yaşamını devam ettirebilmesi, yaşanan bu hızlı değişimlere ayak uydurması ile mümkündür. Eğitim sisteminin temel üretim birimi olan okullar, kendini yenilemek ve geliştirmek zorundadır. Okullarda başarı ve verimliliğin artması; çalışanların fikir ve düşüncelerini, bilgi ve deneyimlerini rahatlıkla ve özgürce ifade edebilmesine bağlıdır. Ancak çalışanların çoğu, okulla ilgili önemli düşünce ve fikirlerini, bilgi ve deneyimlerini isteyerek veya istemeyerek ifade etmemekte, saklamakta ve sessiz kalmayı tercih etmektedirler (Morrison ve Milliken, 2000; Pinder ve Harlos, 2001). Bu bağlamda özellikle okullarda gerek yöneticilerin gerekse öğretmenlerin örgütsel sessizlik algıları ve davranışları, örgüt sağlığını olumsuz yönde etkileyen önemli bir sorun alanı olarak ele alınabilir. Okul yöneticilerinin ve öğretmenlerinin örgütsel sessizlik algıları cinsiyetlerine, statülerine, okul türüne ve kıdemlerine değişiklik gösterebilir. Bu farklılığın nedenlerini ortaya koymak ve bu yönde politikalar üretmek gerekmektedir.

Eğitim örgütlerinin başarısında en önemli öğe öğretmenlerin niteliği ve mesleki yeterlilikleridir. Bundan dolayı ögretmenlerin niteliğini ve mesleki gelişimlerini artırmak önemlidir. Eğitim örgütlerinde öğretmenlerin özgürce düşüncelerini ve fikirlerini ifade etmeleri, yönetim sürecine katılmaları, okulda karşılaşılan sorunlara yönelik çözüm önerileri sunmaları, bilgi, beceri ve deneyimlerini öğrenciler ve meslektaşları ile paylaşmaları eğitimin niteliğini artıracaktır. Öğretmenlerin, yöneticilere güvenmeme, konuşmayı riskli olarak görme, geçmiş yaşantılar, ilişkileri zedeleme korkusu, şikâyetçi ve sorun çıkarıcı görünmek istememeleri gibi nedenlerden dolayı susmaları, okulların gelişimini ve başarısını olumsuz yönde etkileyecektir (Dal ve Başkan, 2018).

\section{Örgütsel Sessizlik}

Türk Dil Kurumu sözlüğünde sessizlik, "ortalıkta gürültü olmama durumu, sükût" olarak tanımlanırken; "sessiz" sesi olmayan, ses çıkarmayan olarak tanımlanmaktadır (TDK, 2019). Sessizlik psikolojide içine kapanma ve sosyolojide toplumsal suskunluk gibi olumsuz bir durum olarak görülmektedir. Ancak, örgütsel anlamda sessizlik bu tanımlar ile örtüşmemektedir (Brown ve Coupland, 2005; Morrison ve Milliken, 2000; Morrison ve Rothman, 2009). Örgütsel sessizlik, çalışanların örgütle ilgili konularda düşünce ve fikirlerini çeşitli nedenlerden dolayı söylememeleri ve sessiz kalmalarıdır (Çalışkan ve Pekkan, 2016; Van Dyne, Soon ve Botero, 2003). Morrison ve Milliken (2000) örgütsel sessizliği "çalışanların örgütsel konular ve sorunlarla ilgili fikir ve düşüncelerini açıkça dile getirmemesi ve kasıtlı olarak saklaması" olarak tanımlamaktadır. Pinder ve Harlos (2001) ve Van Dyne vd. (2003) örgütsel sessizliğin üç türü olduğunu olduğunu ifade etmektedir:

\section{Kabüllenici Sessizlik}

Çalışanların örgütte herhangi bir konu, sorun ya da durum ile ilgili gelişmeleri kabullenmesi sonucunda, fikir, düşünce, bilgi ve görüşlerini söylememesi olarak tanımlanabilir (Taşkıran, 2010). Kabullenici sessizlikte çalışanlar mevcut durumu kabullenerek durumu değiştirme girişiminde bulunmaz ve görüşlerini açıklama çabası içinde olmazlar (Çakıcı, 2008). Bizim kültürümüzde, "Böyle gelmiş böyle gider." sözü kabullenici sessizliği ifade etmekte, bir bakıma çalışanlarda öğrenilmiş çaresizliğin yansıması olarak karşımıza çıkmaktadır. Bu sessizlik türünde çalışanlarda kaderine razı gelme, bilinçli bir itaat ve pasif davranış gösterme eğilimi görülür. Çalışanlar, konuştuklarında mevcut durumda bir değişim olmayacağı, konuşmanın boşuna bir girişim olacağı düşüncesiyle fikir ve düşünceleri isteyerek söylememektedirler (Gökçe, 2013). 


\section{Savunmacı/Korunmacı Sessizlik}

Çalışanların örgütle ilgili konularda fikir ve düşüncelerini açıkladığında gelecek tepkilere karşı kendilerini koruma maksadıyla bilinçli bir şekilde fikir ve düşüncelerini saklama durumu olarak tanımlamıştır (Van Dyne vd., 2003). Çalışanlar kişisel çıkarlarını ve ailelerini korumak için veya kişisel menfaatlerinin zarar görmesi korkusu ile sessiz kalmaktadırlar. Kendini koruma maksadıyla yapılan bu davranış, sorunların yok sayılmasına, kişisel hataların saklamasına ve yeni fikirlerin gizlenmesine neden olmaktadır (Çakıcı, 2008; Pinder ve Harlos, 2001). Korku temelinde bireyin kendini koruma stratejisidir.

\section{Prososyal/Korumacı Sessizlik}

Çalışanların örgüt ile ilgili görüş ve fikirlerini ifade etmeleri durumunda oluşabilecek durumları dikkate alarak örgüt menfaatlerini koruma amaçlı sessiz kalmayı tercih etmesidir (Dyne vd., 2003) Prososyal sessizlikte çalışan, örgütün faydasına gördüğü yerde görüşlerini söyler, zararına gördüğü yerde susmayı tercih eder. Bu sessizlik; örgütsel çıkarları etkileyecek tehditleri önlemek ve örgütü korumak için kasıtll, isteğe bağlı bir davranış halidir (Brinsfield, 2009). Kişi kendisini örgütle özdeşleştirir, kendi varlı̆̆ını örgütün varlığına bağlar. Bir örgüt tarafından baskıyla yaptırılamayan isteğe bağlı bir davranıştır.

Çalışanların sessiz kalma davranışının nedenlerini inceleyen araştırmalarda, örgütsel nedenler; örgüt kültürü, sessizlik iklimi, adaletsizlik, yöneticilerin olumsuz geribildirim korkuları, önyargılar, yöneticinin liderlik anlayışı, kişisel nedenler, güven eksikliği, konuşmanın riskli bulunması, izolasyon korkusu, geçmiş tecrübeler, ilişkileri zedeleme korkusu, karakter özellikleri, ulusal ve kültürel nedenler olarak sıralanabilir (Çakıcı 2007; Çakıcı 2008; Demir ve Öztürk 2001; Pinder ve Harlos 2001). Örgütsel sesizlik çalışanların stres yaşamasına, stres sonucu moral ve motivasyonlarının düşmesine ve çalışanların yeteneklerinin gelişmesine engel olarak performans düşmesine neden olabilir (Brinsfield, 2009). Ayrıca örgütsel sessizlik, örgütün karar almasını, işlevlerini ve verimini olumsuz yönde etkiler; örgütün kendini değiştirmesine ve geliştirmesine engel olabilir (Morrison ve Milliken, 2000).

Öğretmenler; okul örgütünde görüş ve önerilerinin ifade edilmesini riskli olarak algılaması, yöneticilerin otoriter yönetim anlayışları, yönetici performansının düşük olması, yönetime olan güven eksikliği, karşı fikir söylendiğinde suçlanma kaygısı, okul ve yöneticilere yönelik ifadeler karşısında yaptırım uygulanacağ 1 endişesi, kişisel rekabet ve çıkar çatışmaları gibi nedenlerden dolayı okulda sessiz kalmayı tercih etmektedirler (Cemaloğlu, Daşçı ve Şahin, 2013). Alan yazın incelendiğinde yönetici tutum ve davranışlarının örgütsel sessizliğin en büyük nedeni olarak görüldüğü değerlendirilmektedir (Batmunkh, 2011; Cemaloğlu vd., 2013; Çakıcı, 2008; Daşc1, 2014; Kahveci ve Demirtaş, 2013). Örgütsel sessizliğin yaşandığı okullarda öğretmenler; bilgi, beceri ve tecrübelerini yönetici ve meslektaşları ile bilinçli ve kasıtlı olarak paylaşmamakta, onlara yeni fikir ve düşüncelerini yeterli düzeyde aktarmamaktadırlar. Örgütsel sesizlik sonucunda okulda değer ve bilgi paylaşımı yetersiz olmakta, öğretmenlerin ve yöneticilerin performansı düşmekte ve sinerji ortaya çıkmamaktadır (Cemaloğlu, 2012). Alanyazın incelendiğinde, okullarda öğretmenlerin duygu ve düşüncelerini, sorunlarını rahatça ifade edemedikleri, okulda meydana gelen sorunları görmezlikten gelip susmayı tercih ettikleri, hem okul yöneticileri hem de meslektaşlarından aldıkları olumsuz eleştiriler karşısında sessiz kaldıkları belirtilmiştir (Kahveci, 2010; Kolay, 2012).

Örgütsel sesizliğin örgütsel bağl1l1k (Göven ve Şentürk, 2019; Kahveci, 2010); örgütsel vatandaşlık davranışı (Aydın, 2016); örgütsel güven (Kaygın ve Atay, 2014); tükenmişlik (Çitli; 2015); mobbing (Daşc1, 2014); örgütsel adalet (Ü̉nlü, 2015) ve örgütsel sosyalleşme (Dönmez, 2016) gibi birçok değişkenle ilişkisi araştırılmıştır. Öğretmenlerin örgütsel sesizlik algıları üzerinde kıdem değişkeninin etkisi olup olmadığını belirmeye yönelik yapılan çalışmalar değerlendirildiğinde; bazı çalışmalarda anlamlı farklılık bulunduğu (Aydın, 2016; Çakal, 2016; Çiçek-Sağlam ve Yüksel, 2015; Dal, 2017; Dal ve Atanur-Başkan, 2018; Karaman, 2015; Kurudirek, 2016) bazı çalışmalarda ise 
anlamlı bir farklılık bulunmadığ 1 görülmüştür (Çiftçi ve Meriç, 2015; Demir ve Cömert, 2018; Doğan ve Sevgin, 2017; Dönmez, 2016; Kolay, 2012; Sezgin-Nartgün ve Kartal, 2013; Zengin, 2018).

İlgili literatür incelendiğinde çalışanların örgütsel sessizlik algılarında kişisel ve mesleki özellik ve tercihlerin etkisinin olduğu görülmektedir. Özellikle öğretmenlerin hizmet süreleri arttıkça örgütsel sessizlik algılarının değiştiği öngörülmektedir (Akbarian, Ansari, Shaemi, Keshtiaray, 2015; Kahveci, 2010; Premeaux ve Bedeian, 2003). Türkiye'de eğitim alanında örgütsel sesizlik konusuna yönelik yapılan nitel ve nicel çalışmaların sayısı her geçen gün artmaktadır. Okullarda örgütsel sesizlik konusunu ele alan nitel ve nicel yöntemler kullanılarak yapılan araştırmalarda genellikle çeşitli ölçekler ve farklı bağımsız değişkenler (cinsiyet, branş, medeni durum, öğrenim düzeyi vb.) kullanılmıştır. Bu araştırmalar sonucunda, istatistiksel açıdan hem anlamlı hem de anlamlı olmayan ve bağımsız değişkenlerin alt grupları açısından farklılık gösteren sonuçlara ulaşılmıştır. Son yıllarda okullarda öğretmenlerin örgütsel sesizliğine ilişkin görüşlerini konu alan çalışmaların artması, bu sonuçların derlenip örneklem sayıları da dikkate alınarak sentezlenmesi ihtiyacını ortaya koymuştur. Tulunay-Ateş ve Önder (2018) tarafndan yaplan meta-analiz çalışmasında eğitimcilerin örgütsel sesizlik algılarında cinsiyet ve medeni durumun etkisinin düşük düzeyde olduğu görülmüştür. Alanyazın incelendiğinde öğretmenlerin örgütsel sesizliğe ilişkin görüşlerini kıdem değişkeni açısından meta analiz yöntemi ile inceleyen bir çalışmanın olmadığı görülmüştür. Bu meta-analiz çalışması yurt içi ve yurtdışında hem araştırmanın özgün olmasına ve hem de bu alanda farklı değişkenler bağlamında yeni çalışmalar yapılmasına katkı sağlayacaktır. Araştırmanın problemi, öğretmenlerin örgütsel sesizlik algısında kıdemlerinin etkili olup olmadığını belirlemektir. $\mathrm{Bu}$ araştırmanın genel amacı; öğretmenlerin kıdeminin okulda karşılaştıkları örgütsel sesizlik algısına etkisini ortaya koymaktır. Bu genel amaç çerçevesinde;

1. Moderatörlerin (okul türü, öğretim kademesi, öğretmenin ünvanı, araştırmacının cinsiyeti, yayın türü, araştırmanın yapıldığı bölge) öğretmenlerin kıdemleri bağlamında örgütsel sessizlik algılarını etkileme düzeyi nedir?

2. Öğretmenlerin örgütsel sessizlik algıları kıdemleri itibarıyla yıllara göre değişkenlik göstermekte midir?

\section{Yöntem}

Meta-analiz yöntemi aynı konu ile ilgili birbirinden bağımsız olarak yapılmış nicel çalışmaların verilerinin sistematik bir şekilde analiz edillmesi ve sentezlenmesi yöntemidir. Verilerin analizinde meta-analiz türlerinden grup karşılaştırma yöntemi kullanılmıştır. Grup karşılaştırma metaanalizinde, gruplar arası ortalama farkını göstermek için etki büyüklüğü hesaplanmaktadır. Araştırmacı tarafindan deney ve kontrol grubu oluşturulmuşsa, bu meta-analiz türüne grup karşılaştırma meta-analizi denilmektedir (Cumming, 2012, s. 205; Durlak, 1995; Dinçer, 2014; Hartung, 2008). Bir meta-analiz çalışmasında; aynı araştırma sorusuna ve konusuna yönelik tekil ve bağımsız nicel çalışmalar dahil edilme kriterlerine göre seçilir, bu çalışmalardan elde edilen veriler ileri istatistiksel yöntemlerle sentezlenerek etki büyüklükleri belirlenir ve yorumlanır (Dinçer, 2014; Ellis, 2012, s. 5).

\section{Verilerin Toplanması}

Türkiye'de araştırma konusu ile ilgili yüksek lisans ve doktora tezleri ile araştırma makaleleri, bu çalışmanın temel veri kaynağını ve kapsamını oluşturmaktadır. İlgili araştırmalara ulaşmak için Web of Science, Education Resources Information Center (ERIC), Ulusal Akademik A $\breve{g}$ ve Bilgi Merkezi (ULAKBIM), EBSCOhost, Google Akademik ve YÖK Ulusal Tez Merkezi veri tabanlarından "sessizlik", "örgütsel sessizlik", "çalışan sessizliği” anahtar sözcükleri kullanılarak tarama yapılmıştır. Yapılan tarama sonrası araştırma konusuna yönelik yapılan 87 çalışmadan dâhil edilme kriterlerine uygun 33 çalışmanın olduğu belirlenmiştir. Araştırmaya dâhil edilen çalışmaların seçiminde aşağıdaki kriterler esas alınmıştır: 
1. Kriter: Yayınlanmış veya yayımlanmamış çalışma kaynakları: Makale, yüksek lisans ve doktora tezleri alınmıştır.

2. Kriter: Çalışmalardaki araştırma yönteminin uygun olması: Meta-analiz çalışmalarında etki büyüklüğüne ulaşabilmek için dahil edilen çalışmaların ampirik çalışmalar olması ve kıdemin (hizmet süresinin) bağımsız değişken olarak kullanmış olması dikkate alınmıştır.

3. Kriter: Yeterli sayısal veri içermesi: Meta-analiz çalışması için gerekli olan etki büyüklüklerinin hesaplanabilmesi için kıdem değişkeni bağlamında öğretmen grupları için; örneklem büyüklüğü, ortalama, standart sapma, $\mathrm{F}$ değeri, $\mathrm{t}$ değeri, $\mathrm{X}^{2}$ değeri, Kruskal Wallis değeri ve $\mathrm{p}$ değeri dikkate alınmıştır.

Farklı örneklemlerde yapılması (yönetici, öğretim üyeleri) ve meta-analiz için gerekli istatistiksel verilere sahip olmaması nedeniyle 54 çalı̧̧ma araştırmaya dâhil edilmemiştir. $\mathrm{Bu}$ araştırmanın örneklemi, 33 çalışma ve 2010-2019 yılları arasında Türkiye'de bu konuda yapılan yüksek lisans ve doktora tezi çalışmaları ile araştırma makaleleri ile sınırlıdır.

\section{Araştırmanın Güvenirliği ve Geçerliği}

Çalışmaların kimliği, içeriği ve verilerini içeren bir kodlama protokolü ve formu oluşturulmuştur. En az iki kodlayıcı tarafından dahil edilecek çalışmalardaki veriler kodlama protokolüne ayrı ayrı yazılmıştır. Kodlama işlemi yapıldıktan sonra kodlayıcılar arası güvenirliğin (interrater reliability) sağlanması için Cohen's Kappa istatistiği kullanılmış (Lipsey, 2009) ve güvenirlik 0,96 olarak bulunmuştur. Bu sonuç, kodlayıcılar arasında mükemmel bir uyumu göstermektedir (Card, 2012). Meta-analize dahil edilme kriterlerine uygun tüm çalışmaların ulaşılabilecek tüm veri tabanları kullanılarak taranması ve çalışmaya dahil edilmesi, araştırmanın geçerliliğinin bir göstergesidir (Petticrew ve Roberts, 2006). Tarama sonucunda bütün çalışmalara ulaşılması bağlamında geçerliliğin sağlandığı söylenebilir. Bu bağlamda meta-analize dahil edilen 33 çalışmanın her biri ayrıntılı olarak incelenmiş, araştırmada kullanılan veri toplama araçlarının geçerliğinin ve güvenirliğin sağlandığı doğrulanmıştır. Dolayısıyla bu meta-analiz çalışmasının da geçerli olduğu söylenebilir.

\section{Verilerin Analizi}

Bu çalışmada, meta-analiz için İstatistiksel Paket Programı CMA ver. 2.2 [Comprehensive Meta Analysis] kullanılmıştır. Kodlayıcı güvenirliği testi için SPSS ver.20.0 paket programından faydalanılmıştır. Çalışmada deney grubu olarak 1-10 yıl hizmete sahip öğretmenler, kontrol grubu olarak 11 yıl ve üstü hizmet süresine sahip olan öğretmenler alınmıştır. Dolayısıyla hesaplanan etki büyüklüğünün pozitif olması 1-10 yıl hizmet süresine sahip öğretmenler lehine, negatif olması ise 11 y1l ve üstü hizmet süresine sahip öğretmenler lehine yorumlanmaktadır.

\section{Bulgular}

Meta-analiz çalışması kapsamında araştırmalardan elde edilen bulgular (yayın yanlılı̆̆ı, orman grafiği, rastgele etkiler modeli ve moderatör analizi), bu bölümde verilmiştir.

\section{Yayın Yanlılı̆̆ı}

$\mathrm{Bu}$ çalışmada, yayın yanlılığı olup olmadığı iki araç kullanılarak belirlenmiştir: (a) Huni saçılım grafiği, (b) Orwin's Fail-Safe N. (Borenstein, Hedges, Higgins ve Rothstein, 2009). 


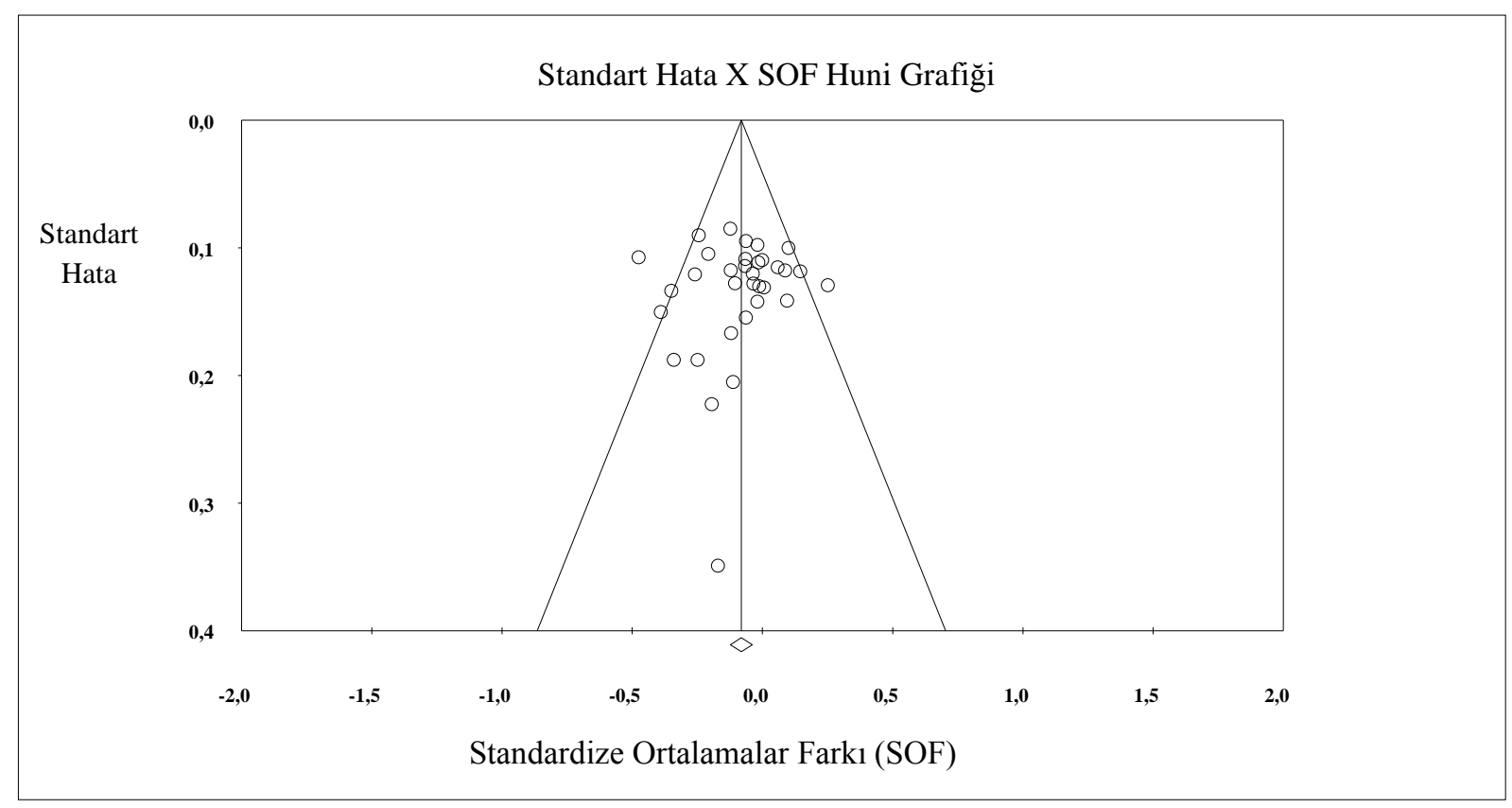

\section{Grafik 1. Huni Saçılım Grafiği}

Grafik 1'de görüldüğü gibi araştırmaya dâhil edilen 33 adet çalışmanın büyük bir çoğunluğu şeklin üst kısmına doğru ve birleştirilmiş etki büyüklüğüne çok yakın bir konumda yer almaktadır. Yayın yanlılığının olmaması durumunda, çalışmaların, birleştirilmiş etki büyüklüğünü gösteren dikey çizginin her iki yanında simetrik bir şekilde yayılmaları beklenmektedir (Borenstein vd., 2009; Dinçer, 2014). Bu anlamda huni saçılım grafiği, araştırmaya dâhil edilen çalışmalar açısından yayın yanlılığının bulunmadığını göstermektedir.

Yayın yanlılığını test etmek için Orwin's Fail-Safe N hesaplaması da yapılmıştır. Orwin's FailSafe N bir meta-analizde eksik olabilecek çalışma sayısını hesaplamaktadır (Borenstein vd., 2009). Bu analizin sonucunda, Orwin's Fail-Safe N 126 olarak hesaplanmıştır. Meta-analiz sonucunda bulunan 0,018 ortalama etki büyüklügünün 0,01 düzeyine (trivial), yani neredeyse sıfir etki düzeyine ulaşabilmesi için gerekli çalışma sayısı 126 adettir. Dâhil edilme kriterlerine göre belirlenen 33 çalışma, Türkiye'de bu araştırma sorusuna yönelik yapılmış tüm çalışmaların (nitel, nicel, kuramsal vb.) tamamıdır. Bunların dışında 126 çalışmaya daha ulaşılması olası olmadığından, bu sonuç, bu meta-analizde yayın yanlılığının olmadığının bir diğer göstergesi olarak kabul edilmiştir. Ayrıca yayın yanlılığı olup olmadığını istatistiksel olarak da hesaplamada kullanılan Kendall'ın Tau katsayısının 0,14 ve $p=0,24$ olduğu görülmüsş, bu durumda p-değerinin anlamlı bir fark yaratmaması yani 0.05 'ten büyük olması beklentisi karşılandığından (Dinçer, 2014) yayın yanlığının olmadığı istatiksel olarak da ortaya konulmuştur.

\section{Kıdem Değişkenine Göre Etki Büyüklüğü Analizinin Birleştirilmemiş Bulguları}

Kıdem değişkenine göre öğretmenlerin örgütsel sesizlik algılarının etki büyüklükleri, standart hata ve \% 95'lik güvenirlik aralığına göre alt ve üst sınırları orman grafiği Grafik 2'de verilmiştir.

Tablo 1

Kıdem Değişkenine Göre Göre Çalışmaların Etki Büyüklükleri

\begin{tabular}{|c|c|c|c|c|c|c|c|c|c|c|}
\hline Model & Çalıșma Ad1 & $\begin{array}{l}\text { Etki } \\
\text { büyüklüğü } \\
\text { (d) }\end{array}$ & $\begin{array}{l}\text { Standart } \\
\text { hata }\end{array}$ & Varyans & $\begin{array}{l}\text { Alt } \\
\text { sinır }\end{array}$ & $\begin{array}{l}\text { Üst } \\
\text { sinır }\end{array}$ & $\begin{array}{l}\text { Z- } \\
\text { Değeri }\end{array}$ & $\begin{array}{l}\mathrm{p}- \\
\text { Değeri }\end{array}$ & $\begin{array}{l}\text { Örneklem } \\
\text { Kadın }\end{array}$ & $\begin{array}{l}\text { Sayıs1 } \\
\text { Erkek }\end{array}$ \\
\hline & F.Aydın,2016 & $-0,59$ & 0,12 & 0,02 & $-0,84$ & $-0,35$ & $-4,75$ & 0,00 & 370 & 80 \\
\hline & Kahveci,2010 & $-0,39$ & 0,15 & 0,02 & $-0,68$ & $-0,09$ & $-2,58$ & 0,01 & 394 & 50 \\
\hline & Dal,2017 & $-0,35$ & 0,13 & 0,02 & $-0,61$ & $-0,09$ & $-2,60$ & 0,01 & 63 & 499 \\
\hline
\end{tabular}




\begin{tabular}{|c|c|c|c|c|c|c|c|c|c|c|}
\hline & Öncü,2017 & $-0,35$ & 0,23 & 0,05 & $-0,79$ & 0,10 & $-1,52$ & 0,13 & 59 & 29 \\
\hline & Uçar,2017 & $-0,26$ & 0,12 & 0,01 & $-0,49$ & $-0,02$ & $-2,12$ & 0,03 & 119 & 162 \\
\hline & Kurudirek,2016 & $-0,25$ & 0,19 & 0,04 & $-0,62$ & 0,12 & $-1,31$ & 0,19 & 66 & 50 \\
\hline & Çakal,2016 & $-0,24$ & 0,09 & 0,01 & $-0,42$ & $-0,07$ & $-2,68$ & 0,01 & 216 & 285 \\
\hline & Çiftçi\&Meriç,2015 & $-0,23$ & 0,26 & 0,07 & $-0,74$ & 0,29 & $-0,86$ & 0,39 & 101 & 17 \\
\hline & Burulday,2018 & $-0,21$ & 0,11 & 0,01 & $-0,41$ & 0,00 & $-1,96$ & 0,05 & 431 & 115 \\
\hline & Nartgün\&Demirer,2012 & $-0,17$ & 0,35 & 0,12 & $-0,85$ & 0,52 & $-0,48$ & 0,63 & 9 & 93 \\
\hline & Karaman,2016 & $-0,12$ & 0,09 & 0,01 & $-0,29$ & 0,05 & $-1,42$ & 0,16 & 289 & 263 \\
\hline & Yangin,2015 & $-0,12$ & 0,12 & 0,01 & $-0,35$ & 0,11 & $-1,02$ & 0,31 & 542 & 83 \\
\hline & Kolay,2012 & $-0,12$ & 0,17 & 0,03 & $-0,45$ & 0,21 & $-0,71$ & 0,48 & 77 & 67 \\
\hline & Sevgin, 2015 & $-0,10$ & 0,13 & 0,02 & $-0,35$ & 0,15 & $-0,81$ & 0,42 & 98 & 162 \\
\hline & Nartgün\&Kartal,2013 & $-0,07$ & 0,22 & 0,05 & $-0,50$ & 0,35 & $-0,35$ & 0,73 & 55 & 35 \\
\hline & Karaman,2015 & $-0,07$ & 0,11 & 0,01 & $-0,29$ & 0,16 & $-0,57$ & 0,57 & 120 & 209 \\
\hline & Özdemir,2015 & $-0,06$ & 0,11 & 0,01 & $-0,28$ & 0,15 & $-0,58$ & 0,56 & 134 & 226 \\
\hline & Yıldırım\&Çarıkçı,2017 & $-0,06$ & 0,16 & 0,02 & $-0,37$ & 0,24 & $-0,40$ & 0,69 & 50 & 248 \\
\hline & Kahveci\&Demirtaş,2013 & $-0,06$ & 0,09 & 0,01 & $-0,25$ & 0,13 & $-0,64$ & 0,52 & 228 & 216 \\
\hline & İşleyici,2015 & $-0,04$ & 0,12 & 0,01 & $-0,27$ & 0,20 & $-0,29$ & 0,77 & 91 & 283 \\
\hline & Köylüoğlu,2015 & $-0,03$ & 0,13 & 0,02 & $-0,28$ & 0,22 & $-0,25$ & 0,80 & 103 & 148 \\
\hline & Güler,2017 & $-0,02$ & 0,14 & 0,02 & $-0,30$ & 0,26 & $-0,12$ & 0,90 & 99 & 98 \\
\hline & Gencer,2018 & $-0,02$ & 0,10 & 0,01 & $-0,21$ & 0,17 & $-0,18$ & 0,86 & 156 & 312 \\
\hline & Aydın,2015 & $-0,01$ & 0,11 & 0,01 & $-0,23$ & 0,21 & $-0,12$ & 0,90 & 102 & 371 \\
\hline & Balli,2018 & $-0,01$ & 0,13 & 0,02 & $-0,27$ & 0,24 & $-0,08$ & 0,94 & 71 & 343 \\
\hline & Ceviz,2017 & 0,00 & 0,11 & 0,01 & $-0,22$ & 0,22 & 0,00 & 1,00 & 224 & 131 \\
\hline & Demir\&Cömert,2018 & 0,01 & 0,13 & 0,02 & $-0,25$ & 0,26 & 0,05 & 0,96 & 111 & 121 \\
\hline & Zengin,2018 & 0,06 & 0,12 & 0,01 & $-0,17$ & 0,29 & 0,52 & 0,61 & 132 & 173 \\
\hline & Çitli,2015 & 0,09 & 0,12 & 0,01 & $-0,14$ & 0,32 & 0,75 & 0,45 & 136 & 152 \\
\hline & Dönmez,2016 & 0,10 & 0,14 & 0,02 & $-0,18$ & 0,37 & 0,68 & 0,50 & 57 & 397 \\
\hline & Kurtulmuş,2018 & 0,10 & 0,10 & 0,01 & $-0,10$ & 0,30 & 1,01 & 0,31 & 185 & 215 \\
\hline & Ünlü, 2015 & 0,15 & 0,12 & 0,01 & $-0,09$ & 0,38 & 1,23 & 0,22 & 99 & 251 \\
\hline & Apak,2016 & 0,25 & 0,13 & 0,02 & 0,00 & 0,51 & 1,95 & 0,05 & 95 & 162 \\
\hline Sabit & & $-0,08$ & 0,02 & 0,00 & $-0,12$ & $-0,03$ & $-3,73$ & 0,00 & 5082 & 6046 \\
\hline Rastgele & & $-0,08$ & 0,03 & 0,00 & $-0,14$ & $-0,03$ & $-2,83$ & 0,00 & 5082 & 6046 \\
\hline
\end{tabular}

Tablo 1'e göre 33 çalışma bağlamında 10 yıl ve üstü kıdeme sahip öğretmenlerin örgütsel sesslzlik algılarının daha yüksek olduğu görülmektedir. Araştırma kapsamındaki 33 çalışmaya ilişkin orman grafiği aşağıda verilmiştir (Grafik 2). 


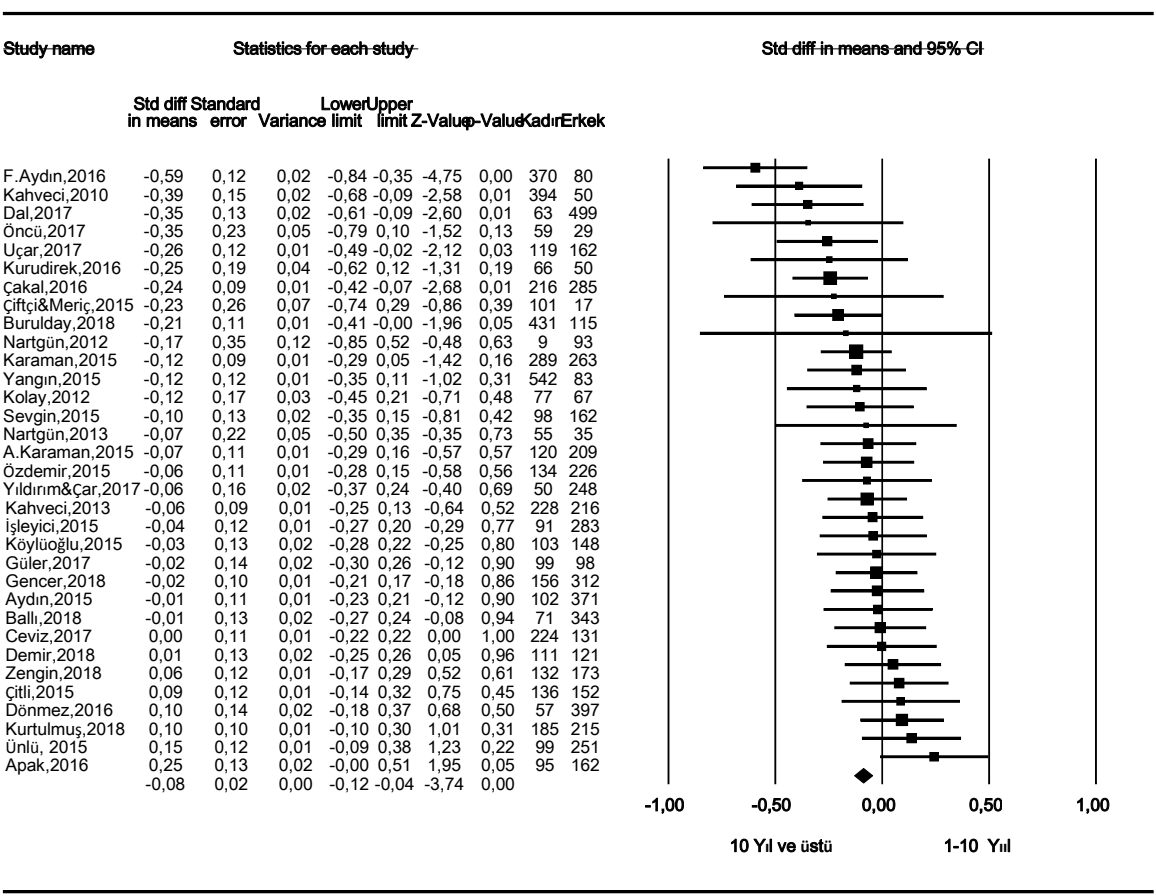

Grafik 2. Kıdem Değişkenine Göre Çalışmaların Etki Büyüklükleri Orman Grafiği

Grafik 2 incelendiğinde 10 yıl ve üstü kıdeme sahip öğretmenler lehine sıfırdan büyük bir farkın olduğu görülmektedir. 10 yıl ve üstü hizmete sahip olan öğretmenler lehine bir farkın olması, öğretmenlerin örgütsel sesizliği meslek yaşamlarının ortalarında ve sonlarında daha fazla yaşadıkları şeklinde yorumlanabilir.

\section{Çalışmaların Etki Büyüklüklerinin Sabit ve Rastgele Etkiler Modeline Göre Birleştirilmiş Bulguları ve Heterojenlik Testi Sonuçları}

Kıdem değişkenine göre öğretmenlerin örgütsel sesizliğe ilişkin algılarının etki büyüklüklerinin sabit ve rasgele etkiler modeline göre birleştirilmiş ortalama etki büyüklüğü (aykırı değerler çıkarılmadan), standart hata ve \% 95'lik güvenirlik aralığına göre alt ve üst sınırları olarak Tablo 2'de verilmektedir.

Tablo 2

Kldem Değişkenine İlişkin Etki Büyüklüğü Meta Analizinin Sabit ve Rastgele Etkiler Modeline Göre Birleştirilmiş, Bulguları ve Homojenlik Testi

\begin{tabular}{|c|c|c|c|c|c|c|c|c|c|c|}
\hline \multirow[t]{2}{*}{ Model } & \multicolumn{6}{|c|}{ Etki büyüklüğü ve $95 \%$ güven aralığ 1} & \multicolumn{3}{|c|}{ Homojenlik } & \multirow[b]{2}{*}{$\mathrm{I}^{2}$} \\
\hline & $\begin{array}{l}\text { Çalışma } \\
\text { sayıs1 }\end{array}$ & $\begin{array}{l}\text { Etki } \\
\text { Büyüklüğü } \\
\end{array}$ & $\begin{array}{l}\text { Standart } \\
\text { hata }\end{array}$ & Varyans & $\begin{array}{l}\text { Alt } \\
\text { sinır }\end{array}$ & $\begin{array}{l}\text { Üst } \\
\text { sinır }\end{array}$ & $\begin{array}{l}Z- \\
\text { değeri }\end{array}$ & $\begin{array}{l}\text { Q- } \\
\text { değeri }\end{array}$ & $\begin{array}{l}\mathrm{df} \\
(\mathrm{Q})\end{array}$ & \\
\hline Sabit etkiler & 33 & $-0,08$ & 0,02 & 0,00 & $-0,12$ & $-0,04$ & 3,37 & 55,93 & 32 & 52,79 \\
\hline $\begin{array}{l}\text { Rastgele } \\
\text { etkiler }\end{array}$ & 33 & $-0,08$ & 0,03 & 0,00 & $-0,14$ & $-0,03$ & 2,85 & & & \\
\hline
\end{tabular}

Tablo 2 kıdem değişkenine göre araştırmaya dâhil edilen çalışmalara ait etki büyüklügü değerlerinin rastgele etkiler modeline göre ortalama etki büyüklüğü değeri $\mathrm{ES}=-0,08$, ortalama etki büyüklüğünün standart hatası $\mathrm{SE}=0,03$, ortalama etki büyüklüğünün güven aralığ 1 üst sınırı 0,03 ve alt sınırı -0,14 olarak hesaplanmıştır. Hesaplamalar doğrultusunda meta analize dâhil edilen 33 
çalışmadaki veriler, rastgele etkiler modeline göre 10 yıl ve üstü kıdeme sahip öğretmenlerin 1-10 yıl kıdeme sahip öğretmenlerden daha fazla örgütsel sesizlik algısına sahip olduklarını göstermektedir. Ancak etki büyüklüğü değeri 0,20 'den düşük olduğu için Cohen'in sınıflandırmasına göre düşük düzeyin de altında bir etkiye sahip olduğu belirlenmiştir (Cohen, 1988). Thalheimer ve Cook'a (2002) ait sınıflandırmaya göre ise önemsiz düzeyde $(-0,15-0,15)$ bir farklılık olduğu görülmüsstür.

İstatistiksel anlamlılık $\mathrm{Z}$ testine göre hesaplandığında $\mathrm{Z}=2,85$ olarak bulunmuştur. Ulaşılan sonucun $\mathrm{p}=0,005$ ile istatistiksel anlamlılığa sahip olduğu belirlenmiştir. Kıdem değişkenine göre araştırmaya dâhil edilen 33 çalışmadan sadece 10'u ortalama etki büyüklüğünün alt ve üst sınırları içerisinde kalarak bulunan etki büyüklüğüne yakın sonuca ulaşmışken, kalan 23 çalışmada ise bu sınırların üstünde ya da altında sonuçlara ulaşılmıştır.

\section{Homojenlik Testi ve $Q$ ve $I^{2}$ İstatistiği}

Homojenlik testi diğer adı ile Q-istatistiği için $Q=55,93$ olarak hesaplanmıştır. Ki kare tablosundan \% 95 anlamlılık düzeyinde 32 serbestlik derecesi değeri 19,49 olarak bulunmuştur. Qistatistik değeri $(\mathrm{Q}=55,93) 32$ serbestlik derecesi ile ki-kare dağılımının kritik değerini $\left(\mathrm{x}^{2} 0,95\right.$ $=19,49$ ) aştığ 1 için etki büyüklüklerinin dağılımına ait homojenliğin yokluk hipotezi sabit etkiler modelinde reddedilmiştir. Yani etki büyüklükleri dağılımının sabit etkiler modeline göre heterojen bir özelliğe sahip olduğu belirlenmiştir. Q istatistiğinin bir tamamlayıcısı olarak geliştirilen $\mathrm{I}^{2}$ ise heterojenliğe ilişkin daha net bir sonuç ortaya koymaktadır. $\mathrm{I}^{2}$ etki büyüklüğüne ilişkin toplam varyansın oranını göstermektedir. $\mathrm{I}^{2}$ istatistiği $\mathrm{Q}$ istatistiğinin aksine çalışma sayısından etkilenmemektedir. $\mathrm{I}^{2}$ nin yorumlanmasında ise $\% 25$ düşük düzeyde heterojenliği, \% 50 orta düzeyde heterojenliği ve \% 75 yüksek düzeyde heterojenliği göstermektedir (Cooper, Hedges ve Valentine, 2009). Kıdem değişkeni için yapılan homojenlik testleri (Q ve $I^{2}$ ) sonucunda çalışmalar arasında yüksek düzeyde heterojenlik bulunduğundan birleştirme işlemi için model rastgele modele çevrilmiştir. Kıdem değişkeni için yapılan homojenlik testleri $\left(\mathrm{Q}\right.$ ve $\left.\mathrm{I}^{2}\right)$ sonucunda çalışmalar arasında orta düzeye yakın bir heterojenlik bulunduğundan, bu heterojenliğin olası nedenlerini belirleyebilmek için moderatör analizleri yapılmıştır.

\section{Kıdem Değişkenine Göre Moderatör Analizi Sonuçları}

Kıdem değişkenine göre ortaya çıkan heterojenliğin nedenlerini ortaya koyabilmek için yapılan moderatör analizi sonuçları Tablo 3'de verilmiştir.

Tablo 3

Örgütsel Sesizliğe Yönelik Kıdemin Etkisine İlişkin Kategorik Moderatör Sonuçları

\begin{tabular}{lccccc}
\hline Moderatör & $\mathrm{k}$ & $\mathrm{d}$ & $\mathrm{SE}$ & $\% 95 \mathrm{CI}$ & $\mathrm{Q}$ \\
Okulöncesi & 1 & $-0,34$ & 0,22 & {$[-0,79 ; 0,10]$} & 6,00 \\
İlkokul & 3 & $-0,04$ & 0,09 & {$[-0,13 ; 0,22$} & \\
Ortaokul & 8 & $-0,13$ & 0,07 & {$[-0,29 ; 0,01]$} & \\
İlköğretim & 6 & $-0,08$ & 0,05 & {$[-0,19 ; 0,02]$} & \\
Ortaöğretim & 8 & $-0,12$ & 0,05 & {$[-0,22 ; 0,01]$} & \\
İlköğretim/Ortaöğretim & 2 & $-0,02$ & 0,19 & {$[-0,40 ; 0,35]$} & \\
Özel Ĕgitim & 1 & $-0,22$ & 0,26 & {$[-0,74 ;-0,28]$} & \\
Tüm & 4 & $-0,02$ & 0,04 & {$[-0,12 ;-0,07]$} & \\
& & & & & \\
\hline Okul Türü & & & & & \\
$\quad$ Resmi & 29 & $-0,07$ & 0,03 & {$[-0,13 ;-0,01]$} & \\
$\quad$ Resmi-Özel & 4 & $-0,15$ & 0,09 & {$[-0,33 ; 0,02]$} & \\
\hline Yayı̈n Türü & & & & & \\
$\quad$ Yüksek lisans & 23 & $-0,08$ & 0,03 & {$[-0,15 ;-0,06]$} & \\
$\quad$ Doktora & 1 & $-0,10$ & 0,09 & {$[-0,19 ; 0,17]$} & 5,74 \\
$\quad$ Makale & 9 & $-0,06$ & 0,04 & {$[-0,19 ;-0,00]$} & \\
\hline Öğretmenin Ünvanı & & & & & \\
Branş & 11 & $-0,15$ & 0,06 & {$[-0,21 ; 0,04]$} & \\
Meslek/Branş & 5 & $-0,08$ & 0,06 & & \\
\hline
\end{tabular}




\begin{tabular}{|c|c|c|c|c|c|}
\hline Okul Öncesi & 1 & $-0,34$ & 0,22 & {$[-0,79 ; 0,10]$} & \\
\hline Özel Eğitim & 1 & $-0,22$ & 0,26 & {$[-0,74 ; 0,28]$} & \\
\hline Sinif & 3 & 0,04 & 0,09 & {$[-0,13 ; 0,22]$} & \\
\hline Sınıf/Branş & 12 & $-0,04$ & 0,03 & {$[-0,11 ; 0,02]$} & \\
\hline Araştırmanın Yapıldığı Bölge & & & & & 8,05 \\
\hline Akdeniz & 4 & $-0,02$ & 0,06 & {$[-0,14 ; 0,10]$} & \\
\hline Doğu Anadolu & 5 & $-0,16$ & 0,06 & {$[-0,29 ; 0,04]$} & \\
\hline Ege & 5 & $-0,15$ & 0,10 & {$[-0,35 ; 0,05]$} & \\
\hline Güney doğu & 1 & 0,10 & 0,10 & {$[-0,09 ; 0,29]$} & \\
\hline İç Anadolu & 4 & $-0,08$ & 0,07 & {$[-0,24 ; 0,06]$} & \\
\hline Karadeniz & 5 & $-0,09$ & 0,07 & {$[-0,23 ; 0,05]$} & \\
\hline Marmara & 8 & $-0,01$ & 0,07 & {$[-0,15 ; 0,12]$} & \\
\hline Türkiye Geneli & 1 & $-0,24$ & 0,01 & {$[-0,61 ; 0,12]$} & \\
\hline Araştırmacının Cinsiyeti & & & & & 1,04 \\
\hline Erkek & 15 & $-0,04$ & 0,03 & {$[-0,12 ;-0,02]$} & \\
\hline Kadın & 13 & $-0,11$ & 0,05 & {$[-0,21 ;-0,01]$} & \\
\hline Kadın/Erkek & 5 & $-0,07$ & 0,07 & {$[-0,21 ;-0,07]$} & \\
\hline
\end{tabular}

Yapılan moderatör analizi sonucunda yayın türüne $(p=0,74)$, okul türüne $(p=0,41)$, öğretim kademesine $(p=0,53)$, araştırmanın yapıldığ araştırmacının cinsiyetine $(p=0,59)$ göre çalışmaların etki büyüklüklerinin farklılaşmadığı belirlenmiştir. Öğretim kademesi açısından okulöncesi eğitim $(\mathrm{d}=-0,32)$ ve özel eğitim $(\mathrm{d}=0,10)$ kademesinde çalışan 10 yıl ve üstü kıdeme sahip öğretmenlerin örgütsel sesizlik algıları diğer kademede çalışan öğretmenlere göre daha yüksek çıkmıştır. Araştırmaların yapıldığ 1 bölgeler bağlamında Güneydoğu Anadolu bölgesi $(\mathrm{d}=0,10)$ dışında yapılan araştırmaların sonuçları, 10 yıl ve üstü kıdeme sahip öğretmenlerin örgütsel sesizlik algılarının yüksek olduğunu göstermektedir.

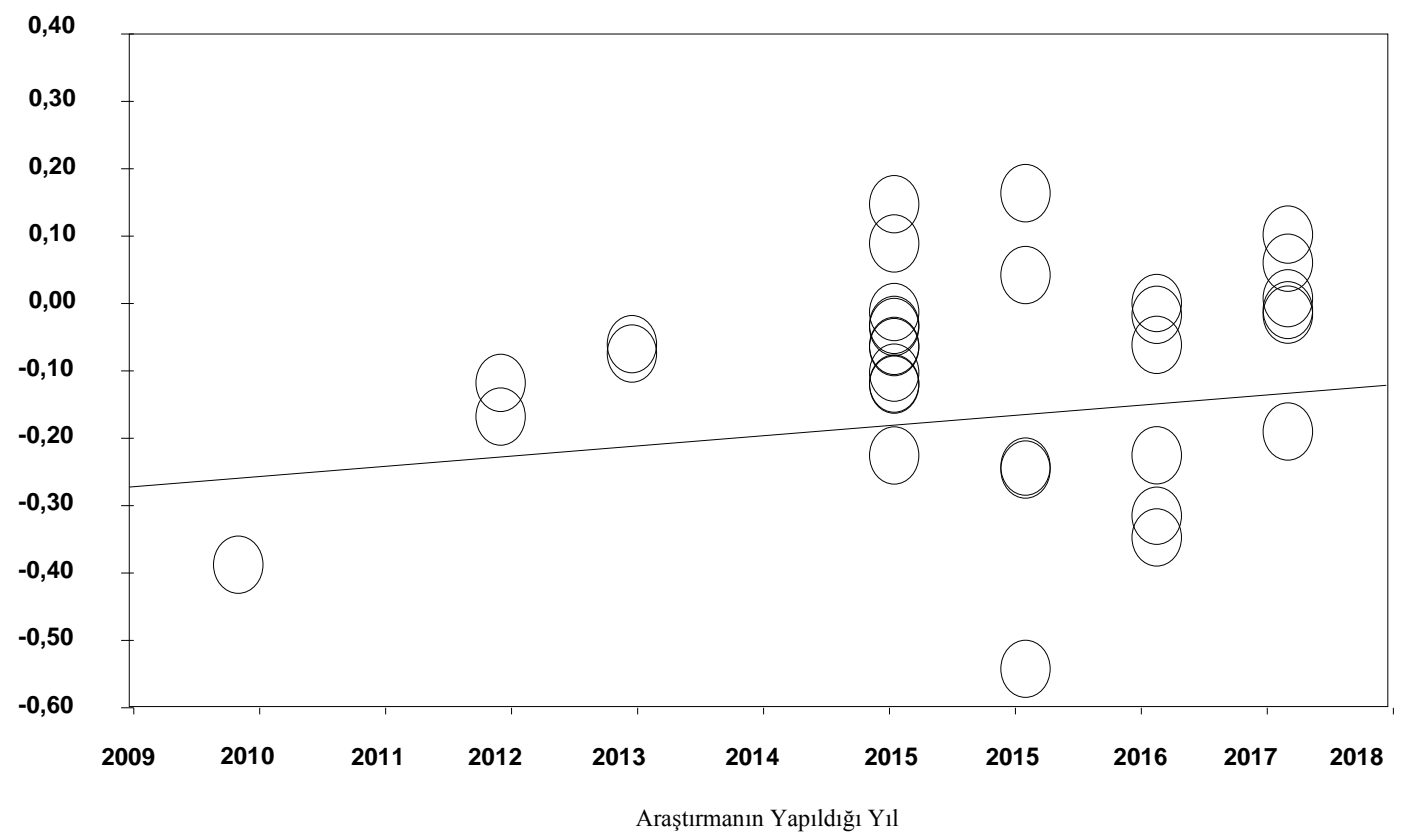

Grafik 3. Araştırmanın Yapıldığı Yıllar İtibariyle Etki Büyüklükleri Meta-regresyon Sonuçları

Grafik 3'de görüldüğü gibi, araştırmalara ait etki büyüklükleri açısından yıllar itibariyle kıdem farklı1ığında 10 yıl ve üstü kıdeme sahip öğretmenlerin örgütsel sessizlik algılarının yüksekliğinin devam ettiği görülmektedir. 


\section{Sonuç, Tartıșma ve Öneriler}

$\mathrm{Bu}$ araştırmanın sonucunda öğretmenlerin örgütsel sesizlik algılarında kıdemlerinin düşük düzeyde etkili olduğu görülmüştür. Bu sonuç, Aydın (2016), Batmunkh (2011), Çiçek-Sağlam ve Yüksel (2015), Dal (2017), Dal ve Atanur-Başkan (2018), Karaman (2015) ve Kurudirek (2016) tarafından yapılan araştırmaların sonuçları ile paralellik göstermektedir. Öğretmenlerin örgütsel sesizlik algılarını konu alan başka bir meta-analiz çalışması olmadığından bu sonuçları karşılaştırma olanağı söz konusu olmamıştır. Araştırmanın yapıldığı yıllar moderatör değişkenine göre araştırmalara ait etki büyüklükleri açısından 10 yıl ve üstü kıdeme sahip öğretmenlerin örgütsel sesizlik algılarında bir artma eğilimi olduğu görülmektedir.

Uçar, (2017), Çiçek-Sağlam ve Yüksel (2015) ve Dal (2017) tarafından yapılan çalışmalarda, 1-10 yıl kıdeme sahip öğretmenlerin 10 yıl ve üstü kıdeme sahip öğretmenlere oranla örgütsel sessizlik algılarının daha yüksek olduğu ortaya koyulmuştur. Bunun nedeni olarak da öğretmenlerin kurumla ters düşmemeyi istemeleri, olumsuz durumdan kaçınmak ve kendinden daha kıdemli öğretmenlere göre sessiz kalmayı tercih etmeleri gösterilmiştir. Öğretmenlerin kıdemi arttıkça kurum yararını daha çok gözettikleri, kıdemi az olan öğretmenlere göre kurumun açıklarını, sırlarını daha iyi gizledikleri, kurumun zarar görmesini önlemek içn sessiz kalmayı tercih ettikleri görülmüştür. Bu meta-analiz çalışması sonuçları bağlamında özellikle 10 yıl ve üstü kıdeme sahip öğretmenlerin kabüllenici ve prososyal sessizlik algılarının daha fazla olduğu söylenebilir. Uçar (2017) tarafindan yapılan çalışmada, öğretmenlerin kıdemlerinin arttıkça sessiz kalma düzeylerinin yükselmesinin nedeni olarak itirazları, önerileri ve fikirlerinin nasıl karşılanacağını, dönütünün nasıl olacağını öngörmeleri ve olumsuz durumlarla karşılaşmamak olduğu ifade edilmiştir. Bu meta-analiz çalışmasının sonucunun aksine Şahin (2016) ve Uğur (2017) tarafından yapılan çalışmalarda, öğretmenlerin kıdemleri arttıkça sessizliği tercih etme oranının azaldığı görülmektedir.

Sonuç olarak okullarda öğretmenlerin örgütsel sesizlik algılarının azaltılmasına yönelik dışsal faktörlerde (okul kültürü, çalışma koşulları, yönetim biçimi, ücret, kariyer olanakları vb.) iyileştirmeler yapılması önerilebilir. Öğretmenlerin örgütsel sesizliğe ilişkin görüşleri bağlamında kıdem değişkeni açısından 10 yıl ve üstü kıdeme sahip öğretmenlerin düşük düzeyde de olsa daha fazla algılamalarının nedenlerinin ortaya çıkartılmasına yönelik nitel ve nicel araştırmalar yapılması önerilebilir. Bu meta analiz çalışması sonuçları bağlamında öğretmenlerin kıdem değişkeni dışında örgütsel sessizliği yordayıcı yönetim biçimi, okul kültürü, branş, okul türü ve cinsiyet gibi değişkenler kullanılarak meta analiz çalışmaları yapılabilir. 


\section{Kaynaklar}

Yıldız imi (*) ile işaretlenmiş kaynaklar, meta-analize dâhil edilen çalışmaları göstermektedir.

Akbarian, A., Ansari M., Shaemi A. and Keshtiaray, N., (2015). Review organizational silence factors. Journal of Scientific Research and Development, 2(1). 178-181.

*Apak, F. (2016). Okul yöneticilerinin gücü kullanma biçimleri ile ögretmenlerin örgütsel sessizlik düzeyleri arasındaki iliş̧ki. Yüksek Lisans Tezi. Okan Üniversitesi, Sosyal Bilimler Enstitüsü, İstanbul.

*Aydın, F. (2016). Ortaokul yöneticilerinin kullandıkları örgütsel güç türleri ve ögretmenlerin örgütsel sessizlik davranışları. Yüksek Lisans Tezi. Pamukkale Üniversitesi, Eğitim Bilimleri Enstitüsü, Denizli.

*Aydın, Y. (2015). Örgütsel sessizliğin okul yönetiminde kayırmacılık ve öğretmenlerin öz yeterlik algısı ile ilişkisi. Yüksek Lisans Tezi. Gazi Üniversitesi, Eğitim Bilimleri Enstitüsü, Ankara.

Aydın, Y. (2016). Örgütsel sessizliğin okul yönetiminde kayırmacılık ve öğretmenlerin öz yeterlik algısı ile ilişkisi. Kuram ve Uygulamada Ĕ̈itim Yönetimi 22(2), 165-192.

Batmunkh, M.(2011). Liderlik tarzlart ile örgütsel bağlllık ve örgütsel sessizlik arasındaki ilişki ve bir araştırma. Yüksek Lisans Tezi. Marmara Üniversitesi Sosyal Bilimler Enstitüsü, İstanbul.

Borenstein, M., Hedges, L. V., Higgins, J. P. T. and Rothstein, H. R. (2009). Introduction to metaanalysis. West Sussex-UK: John Wiley \& Sons Ltd.

Brinsfield, C. T. (2009). Employee silence: Investigation of dimensionality, development of measures, and examination of related factors. Doctoral dissertation, The Ohio State University, USA.

Brown, A. D. and Coupland, C. (2005). Sounds of silence: graduate trainees, hegemony and resistance. Organizations Studies, 26(7), 1049-1069.

*Burulday, V. (2018). Ortaokullarda görev yapan öğretmenlerin örgütsel vatandaşlık, örgütsel sessizlik ve örgütsel tükenmişlik davranışları arasındaki iliş̧kinin incelenmesi. Yüksek Lisans Tezi. Frrat Üniversitesi, Eğitim Bilimleri Enstitüsü, Elazığ.

Card, N. A. (2012). Applied meta-analysis for social science research. New York: The Guilford Press.

Cemaloğlu, N. (2012). Türk eğitim sistemi ve okul yönetimi. Ankara: Pegem Akademi.

Cemaloğlu, N., Daşçı, E. ve Şahin, F. (2013). İlköğretim kurumlarında görev yapan öğretmenlerin örgütsel sessizlik yaşama nedenleri: Nitel bir çalıșma. Akademik Sosyal Araștırmalar Dergisi, $1,112-124$.

*Ceviz, T. (2017). Ortaokul öğretmenlerinin işle bütünleşme ile örgütsel sessizlik davranışları arasındaki iliş̧kinin incelenmesi. Yüksek Lisans Tezi. Gazi Üniversitesi, Eğitim Bilimleri Enstitüsü, Ankara.

Cohen, J. (1988). Statistical power analysis for the behavioral sciences (2nd ed.). New Jersey:Lawrence

Cooper, H., Hedges, L. V. and Valentine, J. C. (2009). The handbook of research synthesis and metaanalysis (2nd ed.). New York: Russell Sage. 
Cumming, G. (2012). Understanding the new statistics. New York: Routledge, Taylor and Francis Group.

*Çakal, G. (2016). Ortaöğretim kurumlarında çalışan öğretmenlerin okul yönetimine katılma ile örgütsel sessizlik algıları arasındaki ilişki (Tekirdağ ili örneği). Yüksek Lisans Tezi. Abant İzzet Baysal Üniversitesi, Eğitim Bilimleri Enstitüsü, Bolu.

Çakıcı, A. (2007). Örgütlerde sessizlik: Sessizliğin teorik temelleri ve dinamikleri. Ç.Ü Sosyal Bilimler Enstitüsü Dergisi, 16( 1), 145-162.

Çakıcı, A. (2008). Örgütlerde sessiz kalınan konular, sessizliğin nedenleri ve algılanan sonuçları üzerine bir araştırma. Ç.Ü. Sosyal Bilimler Enstitüsü Dergisi, 17 (1), 117-134.

Çalışkan, A. ve Pekkan, N.Ü. (2016). Örgütsel sessizliğin iş performansına etkisi: etik ikliminin aracılık rolü. Türk Sosyal Bilimler Araştırmaları Dergisi 2 (1), 1-19.

Çiçek Sağlam, A. ve Yüksel, A. (2015). Liselerde görev yapan öğretmen ve yöneticilerin örgütsel sessizliğe ilişkin görüşleri. International Periodical For The Languages, 10 (7), 317-332.

*Çitli, İ. İ. (2015). Örgütsel sessizlik ile tükenmişlik arasındaki ilişki ve bir araştırma. Yüksek Lisans Tezi. Bahçeşehir Üniversitesi, Sosyal Bilimler Enstitüsü, İstanbul.

*Dal, H. (2017). Ortaöğretim kurumlarında örgütsel sessizliğe ilişkin ögrretmen görüşleri (Ankara ili Çankaya ilçesi örneği). Yüksek Lisans Tezi. Hacettepe Üniversitesi, Eğitim Bilimleri Enstitüsü, Ankara.

Dal, H. ve Atanur-Baskan, G. (2018). Ortaöğretim kurumlarında örgütsel sessizliğe ilişkin öğretmen görüşleri. Kuram ve Uygulamada Eğitim Yönetimi, 24 (1), 45- 91.

*Demir, E. ve Cömert, M. (2018). Ortaokul Öğretmenlerinin Örgütsel Sessizlik Alg1lar1. Mehmet Akif Ersoy Üniversitesi Eğitim Fakültesi Dergisi,(49), 148-165.

Dinçer, S. (2014). Eğitim bilimlerinde uygulamalı meta-analiz. Ankara: PEGEM Akademi Yayıncılık.

*Dönmez, E. (2016). Örgütsel sosyalleşme ile örgütsel sessizlik arasındaki ilişki. Yayımlanmamış Yüksek Lisans Tezi. Pamukkale Üniversitesi, Eğitim Bilimleri Enstitüsü, Denizli.

Ellis, P. D. (2012). The essential guide to effect sizes (5th edition). Cambridge-UK: Cambridge University Press.

*Ery1lmaz-Ballı, F. (2018). Öğretmen algılarına göre okul müdürlerinin gösterdiği karizmatik liderlik davranışlarının okullarda görülen örgütsel sessizliği yordama düzeyi. Yüksek Lisans Tezi. Y1ldız Teknik Üniversitesi, Sosyal Bilimler Enstitüsü, İstanbul.

*Gencer, M. (2018). Güç merkezi oluşturma oyunlarının örgütsel sessizlik ve örgütsel sosyalleşmeye etkisi. Doktora Tezi. Pamukkale Üniversitesi, Eğitim Bilimleri Enstitüsü, Denizli.

Gökçe, N. (2013). Lise ögretmenlerinin örgütsel sessizlik düzeyleri (Maltepe ilçesi örneği). Yüksek Lisans Tezi. Maltepe Üniversitesi, Sosyal Bilimler Enstitüsü, İstanbul.

Göven, E. K. ve Şentürk, İ. (2019). İlkokullarda örgütsel sessizlik ile örgütsel bağl1lık arasındaki ilişki (Eskişehir il merkezindeki ilkokullarda bir çalışma). Eskişehir Osmangazi Üniversitesi Sosyal Bilimler Dergisi, 20 (Özel Sayı), 27-37. 
*Güler, T. (2017). Ortaokul müdürlerinin etik liderlik davranışları ile öğretmenlerin örgütsel sessizlikleri arasındaki iliş̧ki (Antalya ili Manavgat ilçe örneği). Yüksek Lisans Tezi. Uşak Üniversitesi, Sosyal Bilimler Enstitüsü, Uşak.

Hartung, J., Knapp, G. and Sinha, B. K. (2008). Statistical meta-analysis with applications. New Jersey: Wiley Publishing Inc.

*İşleyici, K. (2015). Örgütsel adalet ve örgütsel sessizlik arasındaki ilişkinin incelenmesi (Zonguldak ili örneği). Yüksek Lisans Tezi. Abant İzzet Baysal Üniversitesi, Eğitim Bilimleri Enstitüsü, Bolu.

*Kahveci, G. (2010). İlköğretim okullarında örgütsel sessizlik ile örgütsel bağlllı arasındaki ilişkiler. Yüksek Lisans Tezi. Firat Üniversitesi, Sosyal Bilimler Enstitüsü, Elazığ.

*Kahveci, G. ve Demirtaş, Z. (2013). Okul yöneticisi ve öğretmenlerin örgütsel sessizlik algıları. Eğitim ve Bilim Dergisi, 38 (167), 50-64.

*Karaman, A. (2015). Mobbing ile işgören sessizliği arasındaki ilişki: Afyonkarahisar merkez ilkögretim kurumları örneği. Yüksek Lisans Tezi. Türk Hava Kurumu Üniversitesi, Sosyal Bilimler Enstitüsü, Afyon.

*Karaman, G. (2016). Okul müdürlerinin kullandıkları güç kaynakları ile ögrretmenlerin örgütsel sessizlik davranışları arasındaki ilişsi. Yüksek Lisans Tezi. Dumlupınar Üniversitesi, Eğitim Bilimleri Enstitüsü, Kütahya.

Kaygın, E. ve Atay, M. (2014). Mobbingin örgütsel güven ve örgütsel sessizliğe etkisi-kamu kurumunda bir uygulama. Çukurova Üniversitesi İ̈BF Dergisi, 18(2), 95- 113.

*Kolay, A. (2012). Endüstri meslek liselerinde görev yapan öğretmenlerin örgütsel sessizlik ve örgütsel bağlllıklarl arasındaki ilişki. Yüksek Lisans Tezi. Yeditepe Üniversitesi, Sosyal Bilimler Enstitüsü, İstanbul.

*Köylüoğlu, A. S., Bedük, A., Duman, L. ve Büyükbayraktar, H. H. (2015). Analizing the relation between teachers' organizational slience perception and whistle blowing perception. ProcediaSocial and Behavioral Sciences, 207, 536-545.

*Kurtulmuş, F.Ö. (2018). Öğretmen görüşlerine göre okullarda örgütsel sosyalleşme ve örgütsel sessizlik düzeyleri arasındaki iliş̧kinin incelenmesi. Yüksek Lisans Tezi. Kahramanmaraş Sütçü İmam Üniversitesi, Sosyal Bilimler Enstitüsü, Kahramanmaraş.

*Kurudirek, M.A, Gezer, E, Kurudirek, M.I., Gezer, H., Katkat, D. and Mizrak, O. (2016). Investigation of the correlation between organizational justice and organizational silence of Turkish physical education teachers. International Journal of Sport Studies, 6 (10), 12-619.

Lipsey, M. W. (2009). Identifying interesting variables and analysis opportunities. In H. Cooper, L. V. Hedges ve J. C. Valentine (Eds.), The handbook of research synthesis and meta-analysis. New York: Russell Sage Foundation.

Morrison, E. W. and Rothman, N. B. (2009). Silence and the dynamics of power. J. Greenberg, Marissa S. Edwards (Ed.). Voice and Silence in Organizations, (p. 111-135).

Morrison, E. W. and Milliken, F. J. (2000). Organizational silence: a barrier to change and development in a pluralistic world. Academy of Management Review, 25, 706-725. 
*Nartgün, Ş.S. ve Demirer, S. (2012). Öğretmenlerin örgütsel sinizm ve örgütsel sessizlik hakkındaki görüşleri. Bayburt Eğitim Fakültesi Dergisi, 2 (2), 47-67.

*Nartgün, Ş.S. ve Kartal, V. (2013). Öğretmenlerin örgütsel sessizlik ile iş yaşamında yalnızlık düzeylerine ilişkin görüşleri. Bayburt Eğitim Fakültesi Dergisi, 7 (2), 139-156.

*Öncü, B. (2017). Okul öncesi yöneticilerinin algilanan liderlik stilleri ile okul öncesi ögretmenlerinin yaşadıkları örgütsel sessizlik arasındaki algılarının incelenmesi (Kırıkkale ili örneği). Yüksek Lisans Tezi. Bahçeşehir Üniversitesi, Eğitim Bilimleri Enstitüsü, İstanbul.

*Özdemir, Ş. (2015). Sinlf ögretmenlerinin örgütsel sessizlik ve örgütsel bağlllık düzeyleri arasındaki ilişki (İstanbul-Ümraniye ilçesi örneği). Yüksek Lisans Tezi. Yeditepe Üniversitesi, Eğitim Bilimleri Enstitüsü, İstanbul.

*Öztürk Çiftci, D., Meriç, E. ve Meriç, A. (2015). Örgütsel sessizlik, tükenmişlik ve işten ayrılma niyeti ilişkisi: Ordu ili özel eğitim ve rehabilitasyon merkezlerinde bir uygulama. Journal of International Social Research, 8 (41). 996-1007.

Petitti, D. B. (2000). Meta-analysis, decision analysis, and cost-effectiveness analysis (2nd Ed.). New York: Oxford University Press.

Petticrew, M. and Roberts, H. (2006). Systematic reviews in the social sciences. MA-USA: Blackwell Publishers Ltd.

Pinder, C.C. and Carlos, K.P. (2001). Employee silence: quiescence and acquiescence as responses to perceived injustice. Research in Personnel and Human Resources Management, (20), 331369.

Premeaux, S. F. and Bedeian, A. G., (2003). Breaking the Silence: The Moderating Effects of Self-Monitoring in Predicting Speaking Up in the Workplace. Journal of Management Studies, 40(6), 1537-1562.

*Sevgin, A. (2015). Liselerde çallşan öğretmenlerde örgütsel bă̆lllı ile örgütsel sessizlik arasındaki ilişkinin saptanması (Eyüp İlçe Örneği). Yüksek Lisans Tezi. İstanbul Aydın ve Yıldız Teknik Üniversitesi, Sosyal Bilimler Enstitüsü, İstanbul.

Şahin, H. (2016). Örgütsel sessizlik ve çalışanların performansları arasındaki ilişki: izmir ili çiğli ilçesi devlet ilkokullarına ilişkin bir araştırma. Yüksek Lisans Tezi. Celal Bayar Üniversitesi, Sosyal Bilimler Enstitüsü, Manisa.

Taşkıran, E. (2010). Liderlik tarzının örgütsel sessizlik üzerindeki etkisinde örgütsel adaletin rolü ve bir araştırma. Doktora Tezi. Marmara Üniversitesi, Sosyal Bilimler Enstitüsü, İstanbul.

Tulanay-Ateş, Ö. ve Önder, E. (2018). Eğitimcilerin örgütsel sessizliklerinde cinsiyetin ve medenî durumun etkisi: Bir meta analiz çalışması. Hacettepe Üniversitesi Ĕ̆itim Fakültesi Dergisi, 2, 209-232.

Thalheimer, W. and Cook, S. (2002). How to calculate effect sizes from published research articles: a simplified methodology. Http://Work-Learning.com/Effect_Sizes.Htm adresinden 20 Nisan 2019 tarihinde erişilmiştir.

*Uçar, R. (2017). Öğretmenlerin örgütsel sessizlik düzeylerinin çeşitli değişkenler açısından incelenmesi. Uşak Üniversitesi Sosyal Bilimler Dergisi, 10 (Özel Sayı 2), 209-232. 
Uğur, E. D. (2017). Örgütsel sessizlik iklimi ve çalışan sessizlik davranışlarına iliş̧kin bir araştırma. Yüksek Lisans Tezi. İstanbul Kültür Üniversitesi, Sosyal Bilimler Enstitüsü, İstanbul.

*Ünlü, Y. (2015). Illköğretim ve ortaögrretim ögretmenlerinin örgütsel adalet algllart ve örgütsel sessizlik düzeyleri arasındaki ilişki. Yüksek Lisans Tezi. Sakarya Üniversitesi, Eğitim Bilimleri Enstitüsü, Sakarya.

Van Dyne, L., Soon, A. and Botero, I. C. (2003) Conceptualizing employee silence and employee voice as multidimensional constructs. Journal of Management Studies, 40 (6), 1359-1392.

*Yangın, D. (2015). Etkileşim adaleti ve yöneticiye güven ile ögrretmenlerin örgütsel sessizlik davranışları arasındaki ilişki. Yüksek Lisans Tezi. Ondokuz Mayıs Üniversitesi, Eğitim Bilimleri Enstitüsü, Samsun.

*Yıldırım, A. ve Çarıkçı, O. (2017). Mesleki ve teknik anadolu liselerinde görev yapan eğitim yöneticisi ve öğretmenlerin örgütsel sessizlik düzeylerinin incelenmesi. Süleyman Demirel Üniversitesi Vizyoner Dergisi, 8(19), 33-43.

*Zengin, T. (2018). Okul yöneticilerinin mizah tarzlarının örgütsel sessizliğe etkisi. Yüksek Lisans Tezi. İstanbul Aydın Üniversitesi ve Yıldız Teknik Üniversitesi, Sosyal Bilimler Enstitüsü, İstanbul. 


\section{Extended Abstract}

\section{Introduction}

The most important element in the success of educational organizations is the qualification and professional competence of teachers. Therefore, it is important to increase the quality and professional development of teachers. Teachers can express their thoughts and ideas freely in educational organizations, participate in the management process, offer solutions to problems encountered in school, share their knowledge, skills and experiences with students and colleagues will increase the quality of education. Teachers' silence due to reasons such as not trusting administrators, seeing speech as risky, fear of isolation, past experiences, fear of damaging relations, complaining and problematic will negatively affect the development and success of schools (Dal and Chair, 2018). In the context of this study; it means that teachers do not express their thoughts and ideas on schoolrelated issues for various reasons and remain silent. In recent years, the increasing number of studies on teachers' opinions about the students in schools revealed the need to compile and synthesize these results by taking into account the sample numbers. When the literature was examined, it was seen that there was no study examining teachers' opinions about organizational silence means of meta-analysis method in terms of seniority variable. The problem of the research is to determine whether the experience of teachers is effective in perception of organizational silence. The main purpose of this study is to determine the effect size of seniority in teachers' perceptions. Research scope of organizational silence on the subject of the status of teachers in Turkey, in accordance with article 33 master's and doctoral dissertation research with the inclusion criteria for the study of the relationship between employee and organizational silence is taken. As a result of the browsing, it was seen that there are 33 studies between 2000 and 2019 which are deemed appropriate for the inclusion criteria.

\section{Method}

As one of the methods used to synthesize research results and used in the re-analysis of the findings of empirical studies, meta-analysis method was used in the study. MA and PhD theses and research articles discussing this issue in Turkey were taken into the scope of this study. Keywords such as "silence", "organizational silence", and "teacher silence" were searched in YOK National thesis archive and various search engines (Web of Science, ERIC, ULAKBIM, EBSCOhost, Google Academic) in order to access the related researchesAs a result of this browsing, it was observed that 33 studies were appropriate for the inclusion criteria.

\section{Findings}

Orwin's Fail-Safe $\mathrm{N}$ calculation was also made for publication bias. For the average effect size, which was found as 0,05 as a result of the metaanalysis, to reach the level of 0,01 (trivial) - to reach almost zero effect level - the necessary number of studies is 126 . In other words, it shows how many more studies are needed in order to eliminate significance in meta-analysis findings. However, 33 studies which were included in this study are the total number of studies which meet the inclusion criteria and which are available among all the studies conducted on this subject in Turkey. Since there is not any possibility to reach 126 more studies apart from these 33 studies, the acquired result has been accepted as another indicator of the absence of publication bias in this meta-analysis. In addition, Kendall's Tau coefficient was -0.14 and $\mathrm{p}=0.24$. Since the $\mathrm{p}$-value does not make a significant difference, that is, the expectation that it is greater than 0.05 is met (Dinçer, 2014), it has been shown statistically that there is no bias in the publication. From the point of seniority variable (33 studies), an effect size with statistical significance at an insignificant level $(\mathrm{d}=-0,08)$ was determined for the benefit of teachers with 10 years or more experience as indicated by random effects model. From the point of effect sizes of researches, the difference for the benefit of teachers who have 10 years or more experience has still continued. It was identified that effect sizes of studies do not vary by publication type $(\mathrm{p}=0,74)$, school type $(\mathrm{p}=0,41)$, education level $(\mathrm{p}=0,53)$, the region where study was carried out $(p=0,33)$, teacher branche $(p=0,33)$ and gender of the researcher $(p=0,59)$. In terms of the teaching 
level, pre-school education $(\mathrm{d}=-0.32)$ and special education $(\mathrm{d}=0.10)$ level of teachers with 10 years and older seniority perceptions were higher than the teachers working in the other level. The results of the surveys conducted outside the Southeastern Anatolia region $(\mathrm{d}=0.10)$ in the context of the provinces where the researches were conducted show that teachers with a seniority of 10 years and above have higher perceptions of PM.

\section{Results, Discussion and Suggestions}

As a result of this research, a statistically significant effect size of -0.08 was found in favor of teachers who have seniority of 10 years or more. This result is a low level according to Cohen (1988) and Thalheimer and Cook (2002) classification. When these results are evaluated together, it can be said that the seniority of teachers has a low level of effect on their perceptions. This result parallel with the results of research conducted by Batmunkh (2011), Cicek-Saglam and Yuksel (2015), Kurudirek et al., (2016), Dal and Atanur-Chairman (2018), Karaman (2015), Aydin (2016), Dal (2017). As there was no meta-analysis study on teachers' perceptions, it wasn't possible to compare these results. As a result, improvements in external factors (school culture, working conditions, management style, wage, career opportunities, etc.) may be suggested in order to reduce teachers' perceptions of teachers. In the context of teachers' opinions about the students, it can be suggested that qualitative and quantitative researches should be conducted in order to reveal the reasons why teachers with 10 years or more seniority are perceived more, albeit at a low level. In the context of the results, meta-analysis studies can be performed by using variables such as teachers' predictive management style, school culture, branch, school type and gender, except for seniority variable. 